\title{
Article \\ Recovery of Rare Earth Metals (REMs) from Nickel Metal Hydride Batteries of Electric Vehicles
}

\author{
Manis Kumar Jha ${ }^{1, *}$, Pankaj Kumar Choubey ${ }^{1}$, Om Shankar Dinkar ${ }^{1}$, Rekha Panda ${ }^{1}$, Rajesh Kumar Jyothi ${ }^{2}$ (D), \\ Kyoungkeun Yoo $^{3}$ iD and Ilhwan Park $4, * \mathbb{D}$
}

1 Metal Extraction and Recycling Division, CSIR-National Metallurgical Laboratory, Jamshedpur 831007, India; impankaj.choubey@gmail.com (P.K.C.); omshankarojha@gmail.com (O.S.D.); rekhapanda1608@gmail.com (R.P.)

2 Mineral Resources Research Division, Korea Institute of Geoscience and Mineral Resources, Daejeon 34132, Korea; rkumarphd@kigam.re.kr

3 Department of Energy and Resources Engineering, Korea Maritime and Ocean University (KMOU), Busan 49112, Korea; kyoo@kmou.ac.kr

4 Division of Sustainable Resources Engineering, Faculty of Engineering, Hokkaido University, Sapporo 060-8606, Japan

* Correspondence: mkjha@nmlindia.org (M.K.J.); i-park@eng.hokudai.ac.jp (I.P.)

check for updates

Citation: Jha, M.K.; Choubey, P.K.; Dinkar, O.S.; Panda, R.; Jyothi, R.K.; Yoo, K.; Park, I. Recovery of Rare Earth Metals (REMs) from Nickel Metal Hydride Batteries of Electric Vehicles. Minerals 2022, 12, 34. https://doi.org/10.3390/ $\min 12010034$ Academic Editor: Kenneth N. Han

Received: 30 November 2021 Accepted: 21 December 2021 Published: 25 December 2021

Publisher's Note: MDPI stays neutral with regard to jurisdictional claims in published maps and institutional affiliations.

Copyright: (C) 2021 by the authors. Licensee MDPI, Basel, Switzerland. This article is an open access article distributed under the terms and conditions of the Creative Commons Attribution (CC BY) license (https:// creativecommons.org/licenses/by/ $4.0 /)$.

\begin{abstract}
Nickel metal hydride (NiMH) batteries are extensively used in the manufacturing of portable electronic devices as well as electric vehicles due to their specific properties including high energy density, precise volume, resistance to overcharge, etc. These NiMH batteries contain significant amounts of rare earth metals (REMs) along with Co and Ni which are discarded due to illegal dumping and improper recycling practices. In view of their strategic, economic, and industrial importance, and to mitigate the demand and supply gap of REMs and the limited availability of natural resources, it is necessary to explore secondary resources of REMs. Therefore, the present paper reports a feasible hydrometallurgical process flowsheet for the recovery of REMs and valuable metals from spent NiMH batteries. More than $90 \%$ dissolution of REMs (Nd, Ce and La) was achieved using $2 \mathrm{M} \mathrm{H}_{2} \mathrm{SO}_{4}$ at $75{ }^{\circ} \mathrm{C}$ in $60 \mathrm{~min}$ in the presence of $10 \% \mathrm{H}_{2} \mathrm{O}_{2}(v / v)$. From the obtained leach liquor, the REMs, such as $\mathrm{Nd}$ and $\mathrm{Ce}$, were recovered using 10\% PC88 A diluted in kerosene at eq. $\mathrm{pH} 1.5$ and O/A ratio 1/1 in two stages of counter current extraction. La of 99\% purity was selectively precipitated from the leach liquor in the $\mathrm{pH}$ range of 1.5 to 2.0 , leaving $\mathrm{Cu}, \mathrm{Ni}$ and $\mathrm{Co}$ in the filtrate. Further, $\mathrm{Cu}$ and Ni were extracted with LIX 84 at equilibrium $\mathrm{pH} 2.5$ and 5, leaving Co in the raffinate. The developed process flow sheet is feasible and has potential for industrial exploitation after scale-up/pilot trails.
\end{abstract}

Keywords: NiMH batteries; rare earth metals; leaching; solvent extraction; precipitation

\section{Introduction}

Rare earth metals (REMs) are called critical raw materials due to their economic, strategic and industrial importance [1]. The unavailability of the primary resources for these REMs and supply restrictions imposed by China, compelled the researchers to explore secondary resources for the extraction of REMs [2,3]. In this connection, e-waste is one of the fastest emerging areas for the generation of secondary resources containing REMs [4,5]; e-waste contains a several fold higher concentration of REMs in comparison to their availability in natural resources [6]. One of the most prominent secondary resources of e-waste is nickel metal hydride $(\mathrm{NiMH})$ batteries, which are extensively used in portable electronic devices (e.g., notebook, computers, video recorders, mobile phones, etc.) as well as heavily in electric vehicles (EVs) due to their high energy density, specific volume, resistance to overcharge and no electrolyte consumption during charge and discharge $[7,8]$. Therefore, NiMH batteries are a potential secondary resource of rare earth elements as well 
as of cobalt and nickel. The proper recycling of NiMH batteries will not only add economic value but also protect the environment.

Several authors have reported various recycling methods for the recovery of REMs and other valuable non-ferrous metals from spent NiMH batteries. Three different paths (i.e., mechanical processing, pyrometallurgy and hydrometallurgy) have been employed for the recovery of metallic values from spent NiMH batteries [9]. Mechanical processing, usually consisting of grinding, sieving and bed elutriation, is carried out to recover valuable materials [10]. In pyrometallurgy, thermal separation of REMs, such as $\mathrm{La}, \mathrm{Ce}, \mathrm{Nd}$ and $\mathrm{Pr}$ in oxidized form, is carried out from spent NiMH batteries [11]. Among the three paths, hydrometallurgy is most suitable and appropriate for the refining and recovery of REMs from spent NiMH batteries [12-14].

Different hydrometallurgical processes, such as leaching [15-17], solvent extraction and precipitation [18-20], using various lixiviants, extractants and precipitants, respectively, have been reported for metal extraction from spent NiMH batteries. Yang et al. [20] reported the leaching of REMs using $\mathrm{HCl}$ from waste NiMH batteries. Other impurities were removed using ammonia solution and $99 \%$ rare earth oxides were recovered [20]. Bertuol et al. [18] reported the sulfuric acid leaching of REMs followed by their selective precipitation using $\mathrm{NaOH}$ at $\mathrm{pH}$ 1.2. Fernandes et al. [21] reported the chloride leaching of REMs from NiMH batteries followed by their selective extraction using PC88A. Innocenzi and Veglio [19] also studied the sulfuric acid leaching of REMs from spent NiMH batteries followed by their selective precipitation using $\mathrm{NaOH}$ at $\mathrm{pH}$ below 2. Zhang et al. [22] reported the chloride leaching of REMs followed by solvent extraction using D2EHPA. Xia et al. [23] reported recovery of REMs by a method of leaching using $\mathrm{H}_{2} \mathrm{SO}_{4}$, followed by solvent extraction using Cyanex 923. Finally, REM oxide was obtained using oxalic acid [23]. Two different extractants, D2EHPA diluted in kerosene [24] and Cyanex923 [25], have been used for the extraction of REMs from spent NiMH batteries. The method of chemical precipitation is most used for REM recovery owing to its ease of operation and low cost [20,26]. The use of anhydrous sodium sulfate [27] and sodium hydroxide [19] has been reported for the recovery of REMs from spent NiMH batteries. Pietrelli et al. [28] studied sulfuric acid leaching of REMs, $\mathrm{Ni}, \mathrm{Co}, \mathrm{Cd}$ and $\mathrm{Fe}$ from $\mathrm{NiCd}$ and $\mathrm{NiMH}$ batteries. Ahn et al. [29] reported the recovery of REMs in the form of their mixed oxides using a leaching and precipitation process. However, the selective extraction of $\mathrm{Ce}, \mathrm{La}$ and $\mathrm{Nd}$ from the leach liquor of NiMH has not been discussed in this paper.

The literature review suggests that the precipitation process is not selective for the separation of REMs (e.g., La, Ce and Nd). A combined process, consisting of solvent extraction and precipitation, is needed to be developed to selectively extract the REMs. Therefore, the present study reports a novel hydrometallurgical process consisting of leaching, solvent extraction and precipitation for recovery of REMs, including valuable metals, such as $\mathrm{Cu}$, $\mathrm{Ni}$ and $\mathrm{Co}$, in a closed-loop system, considering the zero-waste discharge concept. REMs were first dissolved in sulfuric acid and thereafter $\mathrm{Ce}$ and $\mathrm{Nd}$ were extracted with PC88A. Subsequently, La was selectively precipitated in a range of $\mathrm{pH} 1.5$ to 2 . Further, $\mathrm{Cu}$ and $\mathrm{Ni}$ were selectively extracted using LIX 84 leaving Co in the raffinate. The developed process flow sheet is novel for the selective extraction of REMs.

\section{Experimental}

\subsection{Materials}

Discarded nickel metal hydride (NiMH) batteries of electric vehicles were collected locally to be used for the experimental purpose. Initially, discarded NiMH batteries were discharged using a saturated solution of sodium chloride. Then, NiMH batteries were pretreated by a crushing and flotation process to separate the black powder, metallic fraction and plastic materials, as shown in Figure 1. The black powder was dissolved in aqua regia to analyze the concentration of metals. The typical composition of black powder is shown in Table 1. 


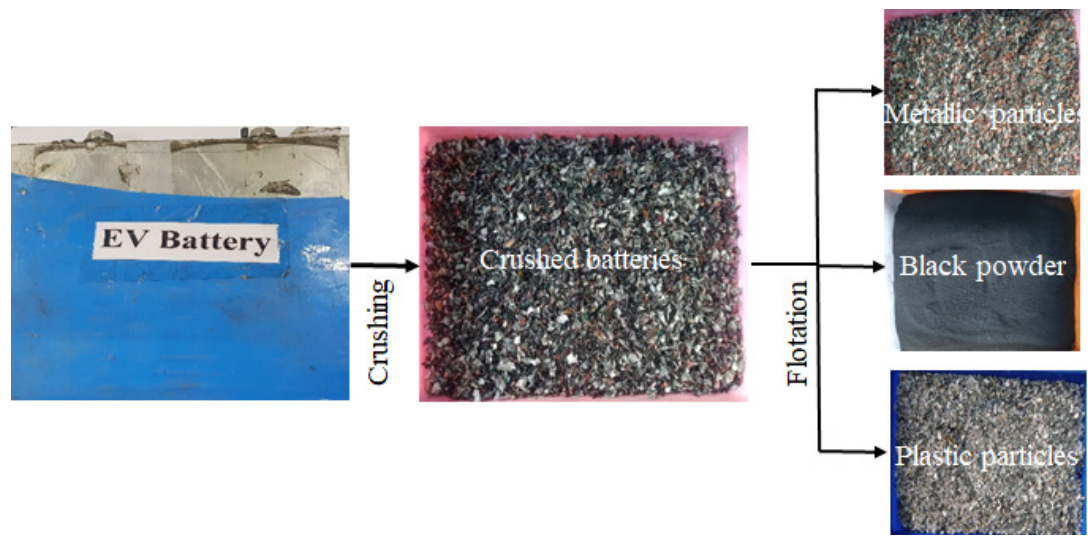

Figure 1. Pre-treatment of discarded electric vehicle batteries.

Table 1. Elemental composition by weight (wt. \%) of the black power of an NiMH battery used in electric vehicles.

\begin{tabular}{cccccccc}
\hline Elements & La & $\mathbf{C e}$ & $\mathbf{N d}$ & $\mathbf{C u}$ & $\mathbf{N i}$ & $\mathbf{C o}$ & Other \\
\hline Contents & 7.7 & 12 & 4.0 & 6.5 & 29 & 5.3 & balance \\
\hline
\end{tabular}

\subsection{Methodology}

\subsubsection{Leaching Procedure}

Leaching experiments were carried out in a three-necked Pyrex glass reactor $(1 \mathrm{~L}$ capacity) fitted with a condenser to condense back the gases evolved during the leaching studies (Figure 2). Hotplates with a temperature sensor and magnetic stirrer facilities were used during leaching experiments. The various concentration of sulfuric acid $(0.5-2.0 \mathrm{M})$ was used as a leachant to dissolve the metals at different temperatures, varying from 25 to $75^{\circ} \mathrm{C}$. When the solution attained the desired temperature, a certain amount of black powder was poured into the solution to leach the metals. Further, the slurry was processed for filtration to obtain leach liquor and leached residue. The dissolved metals present in the leach liquor and remaining in the residue were analyzed using an atomic absorption spectrometer (AAS, AAnalyst 200, Perkin Elmer, Waltham, MA, USA) and inductively coupled plasma-optical emission spectroscopy (ICP-OES, VISTA-MPX, Varian Inc., Victoria, Australia).

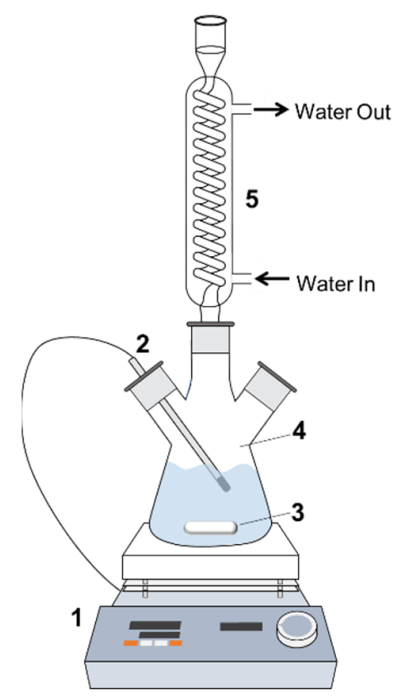
1. Temp. control hot plate
2. Temp. sensor
3. Magnetic bar
4. 3-neck flask
5. Reflux condenser

Figure 2. Experimental setup for leaching of REMs from discarded NiMH batteries. 


\subsubsection{Solvent Extraction Procedure}

Liquid-liquid extraction studies were carried out in a beaker fitted with a magnetic stirrer using an equal volume of leach liquor and extractant ( $25 \mathrm{~mL} / 25 \mathrm{~mL})$. Two types of extractants were used, i.e., 2-ethylhexyl 2-ethylhexyphosphonic acid (PC88A, Figure 3a) for REMs and 2-hydroxy-5-nonylacetophenoneoxime (LIX 84, Figure 3b) for base metals. Kerosene and isodecanol were used as a diluent for extractant and a phase modifier, respectively. Ammonium hydroxide and dilute sulfuric acid were used to maintain the equilibrium $\mathrm{pH}$ (eq. $\mathrm{pH}$ ) in the range of 1 to 5 . When the solution attained equilibrium, the organic and aqueous phases were separated using a separating funnel and the concentrations of metal ions in the raffinate solution were analyzed using ICP-OES. The concentrations of metals in the organic phase were calculated.

(a)

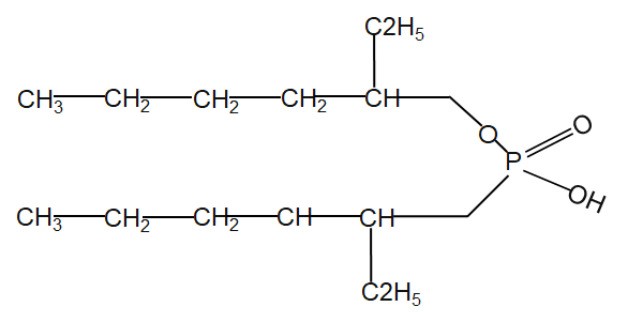

(b)<smiles>CCCCCCc1ccc(O)c(C(C)=O)c1</smiles>

Figure 3. Structure of (a) PC88A and (b) LIX 84.

\subsubsection{Precipitation Procedure}

Precipitation studies were carried out in a beaker (capacity: $100 \mathrm{~mL}$ ) under constant stirring speed at room temperature using ammonium hydroxide as a precipitant. During the experiments, solution $\mathrm{pH}$ was varied between 0.75 and 2.0 by adding ammonium hydroxide to precipitate La as lanthanum hydroxide. The solution was taken at different intervals of time to analyze the concentrations of metals in leach liquor after precipitation.

\subsubsection{Characterization and Analysis of Samples}

X-ray diffraction (XRD, D8, Bruker AXS Inc., Wisconsin, WI, USA) was used to analyze the phases of samples. Figure 4 shows that XRD patterns mainly contained the peak of oxides of rare earth metals, $\mathrm{Cu}$ and $\mathrm{Ni}$ in black powder of $\mathrm{NiMH}$ batteries. Further, AAS and ICP-OES were used to analyze the concentrations of metal ions in the leach liquor.

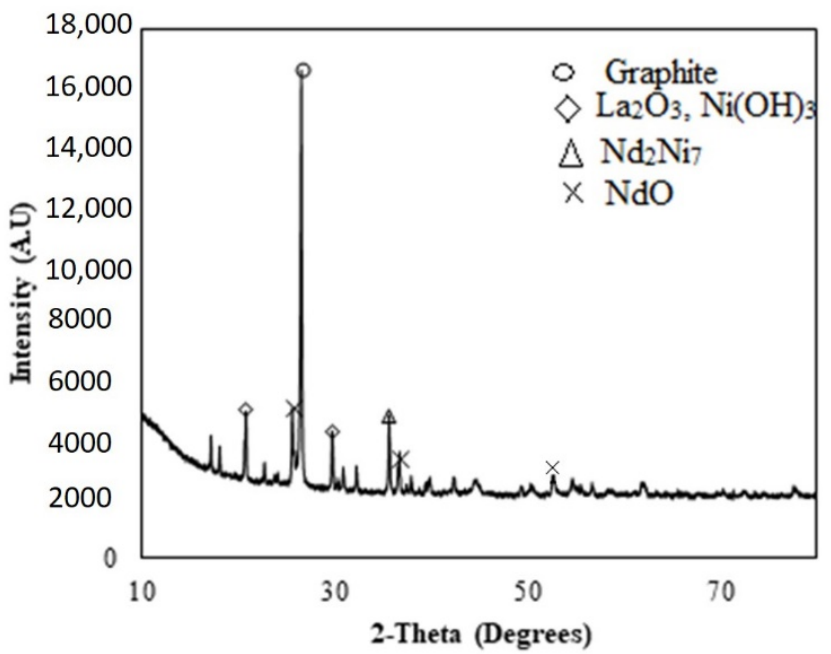

Figure 4. XRD pattern of black powder obtained from NiMH batteries. 


\section{Results and Discussion}

Experiments were carried out using leaching followed by solvent extraction and precipitation to extract the REMs. The obtained results are discussed below:

\subsection{Leaching Studies}

To dissolve the metals and optimize the process parameters (i.e., acid concentration, time, temperature, pulp density, etc.), the leaching experiments were carried out varying the scale of the parameters.

\subsubsection{Effect of Acid Concentration}

To optimize the minimum acid requirement during the leaching experiments, studies were performed varying the sulfuric acid concentration in a range of 0.5 to $2.0 \mathrm{M} \mathrm{H}_{2} \mathrm{SO}_{4}$ at $75{ }^{\circ} \mathrm{C}$ for mixing time $75 \mathrm{~min}$ at pulp density $100 \mathrm{~g} / \mathrm{L}$ in presence of $10 \% \mathrm{H}_{2} \mathrm{O}_{2}(\mathrm{v} / \mathrm{v})$.

The results (Figure 5a-f) showed that leaching of $\mathrm{La}, \mathrm{Ce}, \mathrm{Nd}, \mathrm{Cu}, \mathrm{Ni}$ and $\mathrm{Co}$ increased with increase in the concentration of acid, which happened due to the increase in acidic strength. It was found that $99.1 \% \mathrm{La}, 96.1 \% \mathrm{Ce}, 99.1 \% \mathrm{Nd}, 99.9 \% \mathrm{Cu}, 99.9 \% \mathrm{Ni}$ and $99 \% \mathrm{Co}$ leached in $2 \mathrm{M} \mathrm{H}_{2} \mathrm{SO}_{4}$ at $75{ }^{\circ} \mathrm{C}$ in $60 \mathrm{~min}$. Further, the increase in acidic concentration had no significant effect on the enhancement of REM leaching efficiency. Therefore, $2 \mathrm{M} \mathrm{H}_{2} \mathrm{SO}_{4}$ was considered the optimum acid concentration for the dissolution of metals from black powder of spent electric vehicle batteries.

\subsubsection{Effect of Temperature}

To optimize the temperature for dissolution of REMs, experiments were carried out in a range of temperatures varying from 25 to $75{ }^{\circ} \mathrm{C}$ at a pulp density of $100 \mathrm{~g} / \mathrm{L}$ in the presence of $10 \% \mathrm{H}_{2} \mathrm{O}_{2}(\mathrm{v} / \mathrm{v})$. Figure 6 shows that leaching of $\mathrm{La}, \mathrm{Ce}, \mathrm{Nd}, \mathrm{Cu}, \mathrm{Ni}$ and $\mathrm{Co}$ increased with increase in temperature due to the decrease in activation energy, resulting in the enhancement of metal leaching efficiency with rise in solution temperature [30]. It was found that $98.9 \% \mathrm{La}, 98.5 \% \mathrm{Nd}, 89.9 \% \mathrm{Ce}, 99 \% \mathrm{Cu}, 99 \% \mathrm{Ni}$ and $95.9 \%$ Co leached at $75^{\circ} \mathrm{C}$. Thereafter, the increase in the solution temperature had no significant effect on the enhancement of metal leaching efficiency.

\subsubsection{Effect of Pulp Density}

Pulp density is an important parameter for the effective leaching of metals from solid. Therefore, to optimize the solid to liquid ratio (i.e., pulp density (S/L)), leaching experiments were carried out varying the pulp density from 50 to $200 \mathrm{~g} / \mathrm{L}$ at temperature $75^{\circ} \mathrm{C}, \mathrm{H}_{2} \mathrm{O}_{2} 10 \%(\mathrm{v} / \mathrm{v})$ and mixing time $60 \mathrm{~min}$ for maximum dissolution of REMs. The results (Figure 7) showed that leaching of $\mathrm{La}, \mathrm{Ce}, \mathrm{Nd}, \mathrm{Cu}, \mathrm{Ni}$ and $\mathrm{Co}$ was found to decrease with increase in pulp density above $100 \mathrm{~g} / \mathrm{L}$. This may have been due to increase in the total number of moles of metallic constitutes $(\mathrm{Nd}, \mathrm{La} \mathrm{Ce}, \mathrm{Cu}, \mathrm{Ni}$ and $\mathrm{Co}$ ) relative to available leachant molecules resulting in a decrease in the leaching efficiency of metals [31]. Therefore, $100 \mathrm{~g} / \mathrm{L}$ pulp density has been chosen as the optimum condition for leaching of metals from black powder of NiMH batteries of electric vehicles.

\subsection{Separation and Purification Studies}

\subsubsection{Solvent Extraction of $\mathrm{Ce}$ and $\mathrm{Nd}$}

Leach liquor containing $3.9 \mathrm{~g} / \mathrm{L} \mathrm{Nd} 11.9 \mathrm{~g} / \mathrm{L} \mathrm{Ce} ; 7.6 \mathrm{~g} / \mathrm{L} \mathrm{La} ; 6.5 \mathrm{~g} / \mathrm{L} \mathrm{Cu} ; 28.9 \mathrm{~g} / \mathrm{L} \mathrm{Ni}$ and $5.1 \mathrm{~g} / \mathrm{L}$ Co was used for the solvent extraction studies using 10\% PC88A to selectively separate the rare earth metals. It was found that extraction of $\mathrm{Nd}$ and $\mathrm{Ce}$ increased with increase in eq. $\mathrm{pH}$, as shown in Figure 8. The maximum separation of $\mathrm{Ce}$ and $\mathrm{Nd}$ with respect to $\mathrm{La}, \mathrm{Cu}, \mathrm{Ni}$ and $\mathrm{Co}$ occurred at eq. $\mathrm{pH}$ 1.5. The separation factor $(\beta)$ values of $\mathrm{Nd}$ and $\mathrm{Ce}$ were also calculated with respect to La and found to be $12.1\left(\beta_{\mathrm{Nd} / \mathrm{La}}\right)$ and 56.33 $\left(\beta_{\mathrm{Ce} / \mathrm{La}}\right)$ with respect to La. This indicates that selective extraction of $\mathrm{Nd}$ and Ce can be achieved by increasing the number of stages for extraction of $\mathrm{Nd}$. Thus, a McCabe-Thiele plot was drawn to determine the number of stages required for the extraction of $\mathrm{Nd}$ from 
leach liquor. It was found that two counter-current stages were required to completely extract $\mathrm{Nd}$ from leach liquor, as shown in Figure 9.
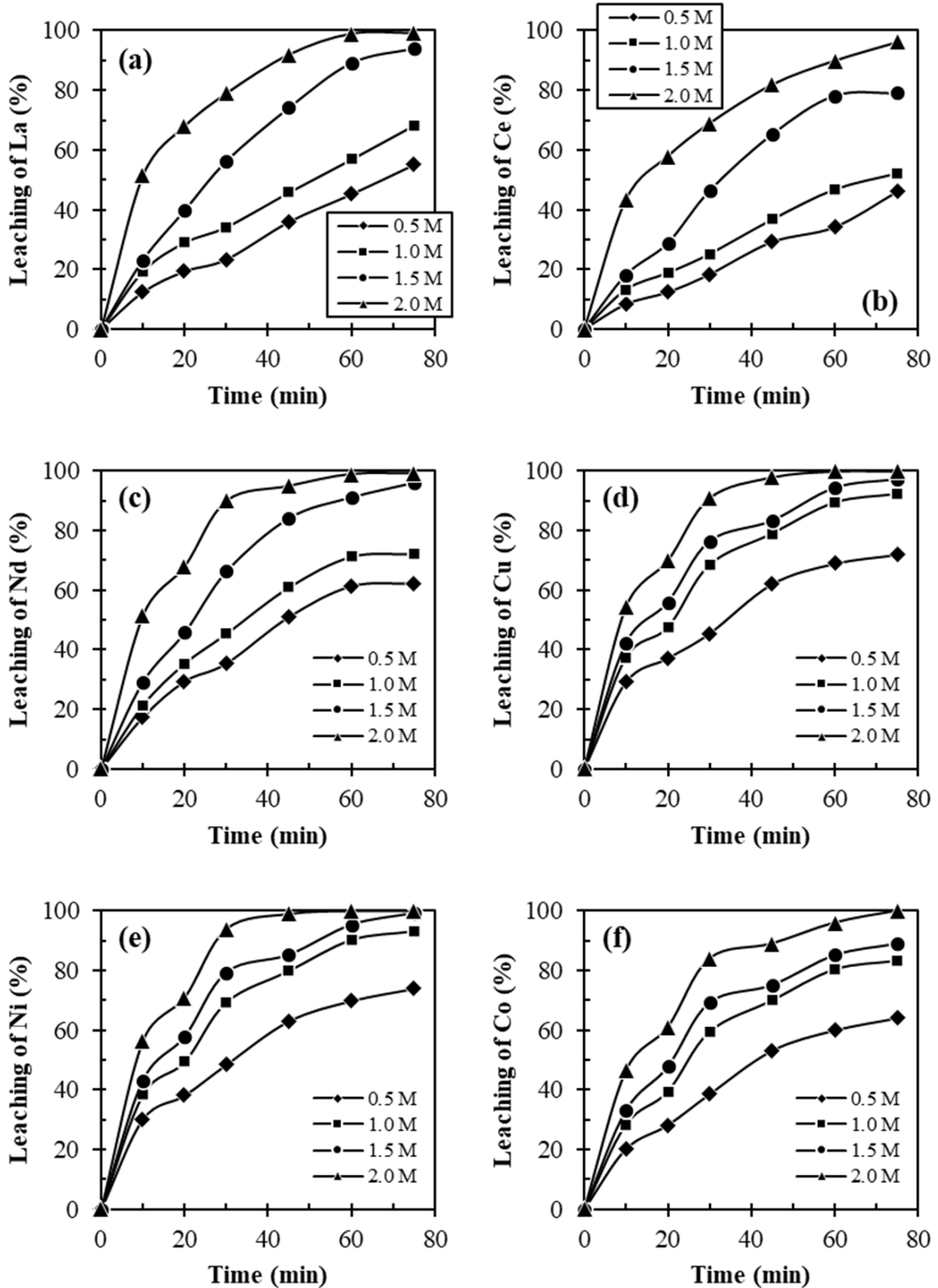

Figure 5. Effect of acid concentration on leaching of (a) $\mathrm{La},(\mathbf{b}) \mathrm{Ce},(\mathbf{c}) \mathrm{Nd},(\mathbf{d}) \mathrm{Cu},(\mathbf{e}) \mathrm{Ni}$ and (f) $\mathrm{Co}$ from black powder of spent NiMH battery of electric vehicle [Solid: black powder; liquid: 0.5-2.0 M $\mathrm{H}_{2} \mathrm{SO}_{4}$; additive: $10 \% \mathrm{H}_{2} \mathrm{O}_{2}(v / v)$; temperature: $75^{\circ} \mathrm{C}$; pulp density $100 \mathrm{~g} / \mathrm{L}$; time: $75 \mathrm{~min}$ ]. 


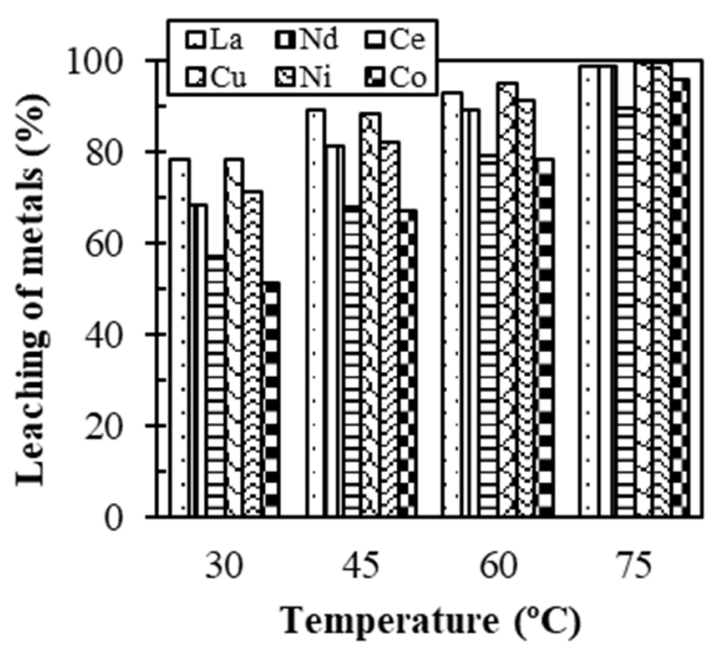

Figure 6. Effect of temperature on leaching of rare earth elements ( $\mathrm{La}, \mathrm{Ce}$ and $\mathrm{Nd}$ ) and valuable metals ( $\mathrm{Cu}, \mathrm{Ni}$ and $\mathrm{Co}$ ) [Solid: black powder; liquid: $2 \mathrm{M} \mathrm{H}_{2} \mathrm{SO}_{4}$; additive: $10 \% \mathrm{H}_{2} \mathrm{O}_{2}(v / v)$; pulp density $100 \mathrm{~g} / \mathrm{L}$; time: $60 \mathrm{~min}]$.

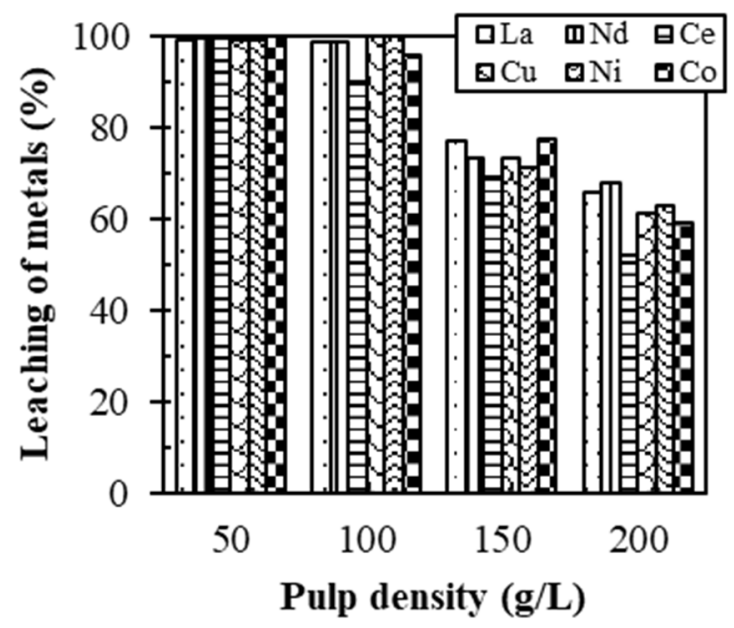

Figure 7. Effect of pulp density on the leaching of rare earth elements ( $\mathrm{La}, \mathrm{Ce}$ and $\mathrm{Nd}$ ) and valuable metals ( $\mathrm{Cu}, \mathrm{Ni}$ and $\mathrm{Co}$ ) [Solid: black powder; liquid: $2 \mathrm{M} \mathrm{H}_{2} \mathrm{SO}_{4}$; additive: $10 \% \mathrm{H}_{2} \mathrm{O}_{2}(v / v)$; time: 60 min; temperature: $\left.75^{\circ} \mathrm{C}\right]$.

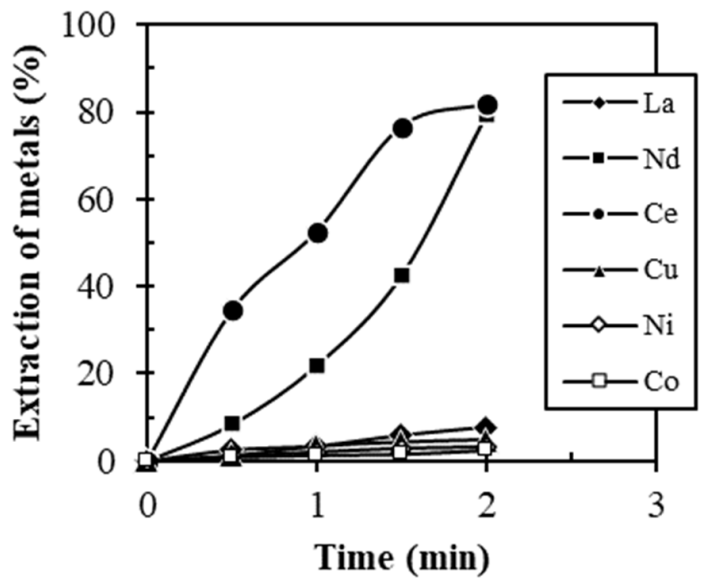

Figure 8. Solvent extraction of $\mathrm{Ce}$ and $\mathrm{Nd}$ from leach liquor [Metal concentration in leach liquor (g/L): Nd: 3.9; Ce: 11.9; La: 7.6; Cu: 6.5; Ni: 28.9; Co:5.1; extractant: 10\% PC88A diluted in kerosene; time: $10 \mathrm{~min}$; $\mathrm{O} / \mathrm{A}$ ratio: $1 / 1$ ]. 


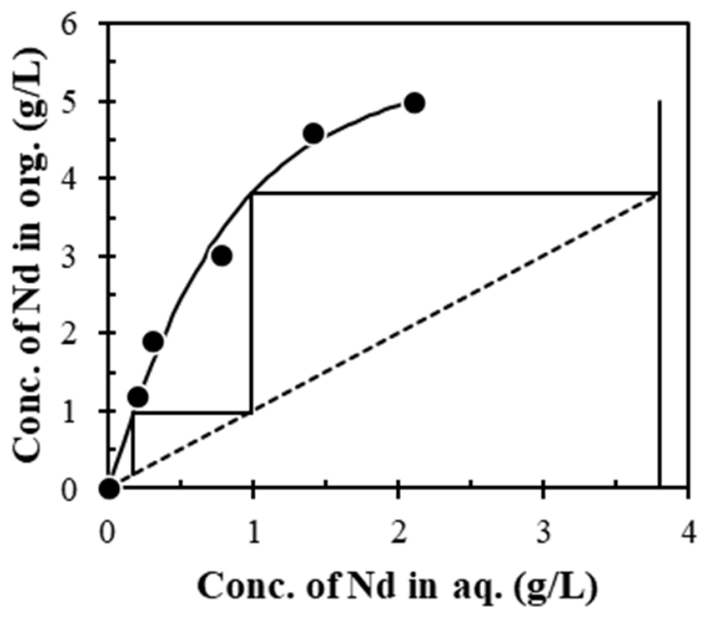

Figure 9. McCabe-Thiele plot for extraction of $\mathrm{Nd}$ from leach liquor [Leach liquor: $3.9 \mathrm{~g} / \mathrm{L} \mathrm{Nd}$; extractant: $10 \%$ PC88A diluted in kerosene; time: $10 \mathrm{~min}$; O/A ratio: 1/1].

\subsubsection{Precipitation of La}

The solution obtained after extraction of $\mathrm{Nd}$ and Ce that contained $7.6 \mathrm{~g} / \mathrm{L} \mathrm{La} ; 6.5 \mathrm{~g} / \mathrm{L}$ $\mathrm{Cu} ; 28.9 \mathrm{~g} / \mathrm{L} \mathrm{Ni}$ and $5.1 \mathrm{~g} / \mathrm{L}$ Co was used for recovery of La by precipitation process. It was found that precipitation of La increased with increase in $\mathrm{pH}$ as shown in Figure 10. The complete precipitation of La occurred at $\mathrm{pH} \sim 1.5$ leaving $\mathrm{Cu}, \mathrm{Ni}$ and Co remaining in the filtrate. Further, precipitation of La was validated with an Eh-pH diagram, which indicated that La precipitation occurred at or above $\mathrm{pH} 1.5$ as $\mathrm{La}(\mathrm{OH})_{3}$ [31], while $\mathrm{Cu}$, $\mathrm{Ni}$ and $\mathrm{Co}$ form hydroxide above $\mathrm{pH}$ 5. Therefore, selective precipitation of La occurred between $\mathrm{pH} 1.5$ and 2.0. Further, $\mathrm{Cu}, \mathrm{Ni}$ and $\mathrm{Co}$ were separated by solvent extraction, as discussed below.

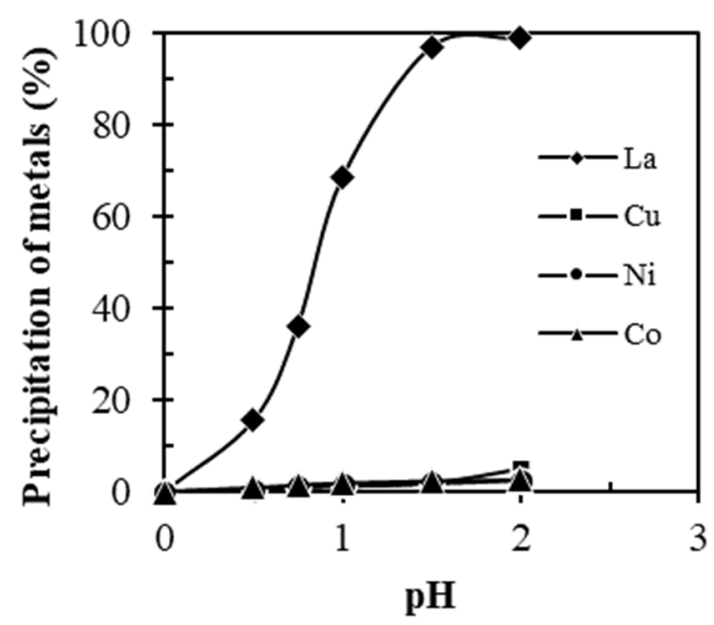

Figure 10. Precipitation of La from leach liquor [Metal concentration in leach liquor (g/L): La: 7.6; Cu: 6.5; Ni: 28.9; Co: 5.1; precipitant: ammonium hydroxide].

\subsubsection{Extraction of $\mathrm{Cu}, \mathrm{Ni}$ and $\mathrm{Co}$}

After the extraction of $\mathrm{La}, \mathrm{Ce}$ and $\mathrm{Nd}$, the obtained solution containing $6.5 \mathrm{~g} / \mathrm{L} \mathrm{Cu}$, $28.9 \mathrm{~g} / \mathrm{L} \mathrm{Ni}$ and $5.1 \mathrm{~g} / \mathrm{L}$ Co was used for selective extraction of $\mathrm{Cu}, \mathrm{Ni}$ and $\mathrm{Co}$ using solvent extraction process. Solvent extraction experiments were carried out with LIX 84 varying eq. $\mathrm{pH}$ between 1.0 and 5.0 to extract the $\mathrm{Cu}, \mathrm{Ni}$ and $\mathrm{Co}$ separately from leach liquor. The results (Figure 11) showed that $99.1 \%$ extraction of Cu occurred with $10 \%$ LIX 84 in a range of eq. $\mathrm{pH} 2.0$ to 2.5 while $\mathrm{Ni}$ and Co remained in the raffinate. Further, $98.6 \% \mathrm{Ni}$ was selectively extracted with $30 \%$ LIX 84 between eq. $\mathrm{pH} 4.5$ and 5.0 at $\mathrm{O} / \mathrm{A}$ ratio $1 / 1$ in $10 \mathrm{~min}$, leaving $\mathrm{Co}$ in the raffinate. This indicates that LIX 84 makes complexes with $\mathrm{Cu}$ and 
$\mathrm{Ni}$ at different eq. $\mathrm{pH}$ resulting in the selective extraction of $\mathrm{Cu}$ and $\mathrm{Ni}$. The metal-loaded organic was stripped using $10 \% \mathrm{H}_{2} \mathrm{SO}_{4}$ to obtain a pure solution of $\mathrm{Cu}$ and Ni. Finally, a process flow sheet was developed for the extraction of $\mathrm{La}, \mathrm{Ce}, \mathrm{Nd}, \mathrm{Cu}, \mathrm{Ni}$ and $\mathrm{Co}$, as shown in Figure 12. The metals/salts of $\mathrm{Nd}, \mathrm{Ce}$ and La could be used in various applications, such as making magnets for hard disks, cathode ray tubes and phosphor powder, and pyrophoric alloys, respectively. In addition, the recovered REMs, $\mathrm{Cu}, \mathrm{Ni}$ and $\mathrm{Co}$ can be re-used in the manufacture of rechargeable batteries. Based on the obtained results and pure metals/salts, the recovered materials of discarded NiMH can be used in different industries after scale-up/pilot trial.

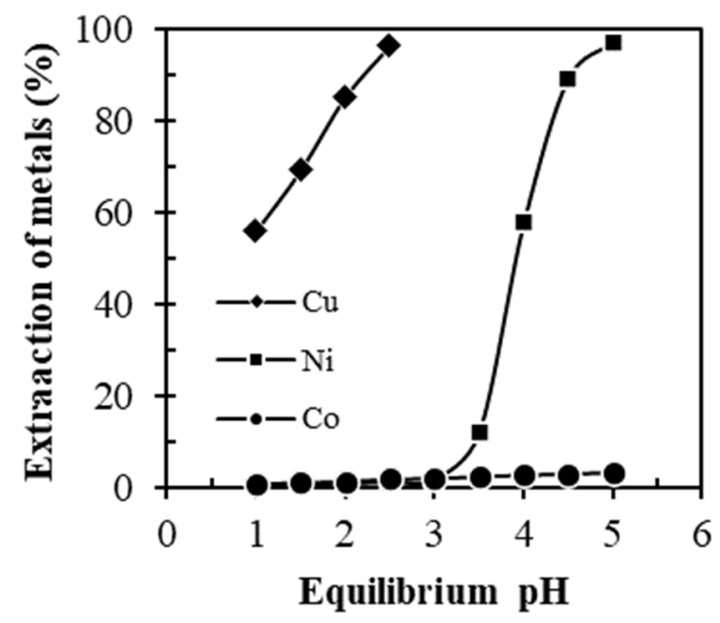

Figure 11. Solvent extraction of $\mathrm{Cu}, \mathrm{Ni}$ and $\mathrm{Co}$ from leach liquor (Metals concentration in leach liquor (g/L): Cu: 6.5; Ni: 28.9; Co: 5.1; extractant: 10\% \& 30\% LIX 84; time: 10 min; O/A ratio: 1/1).

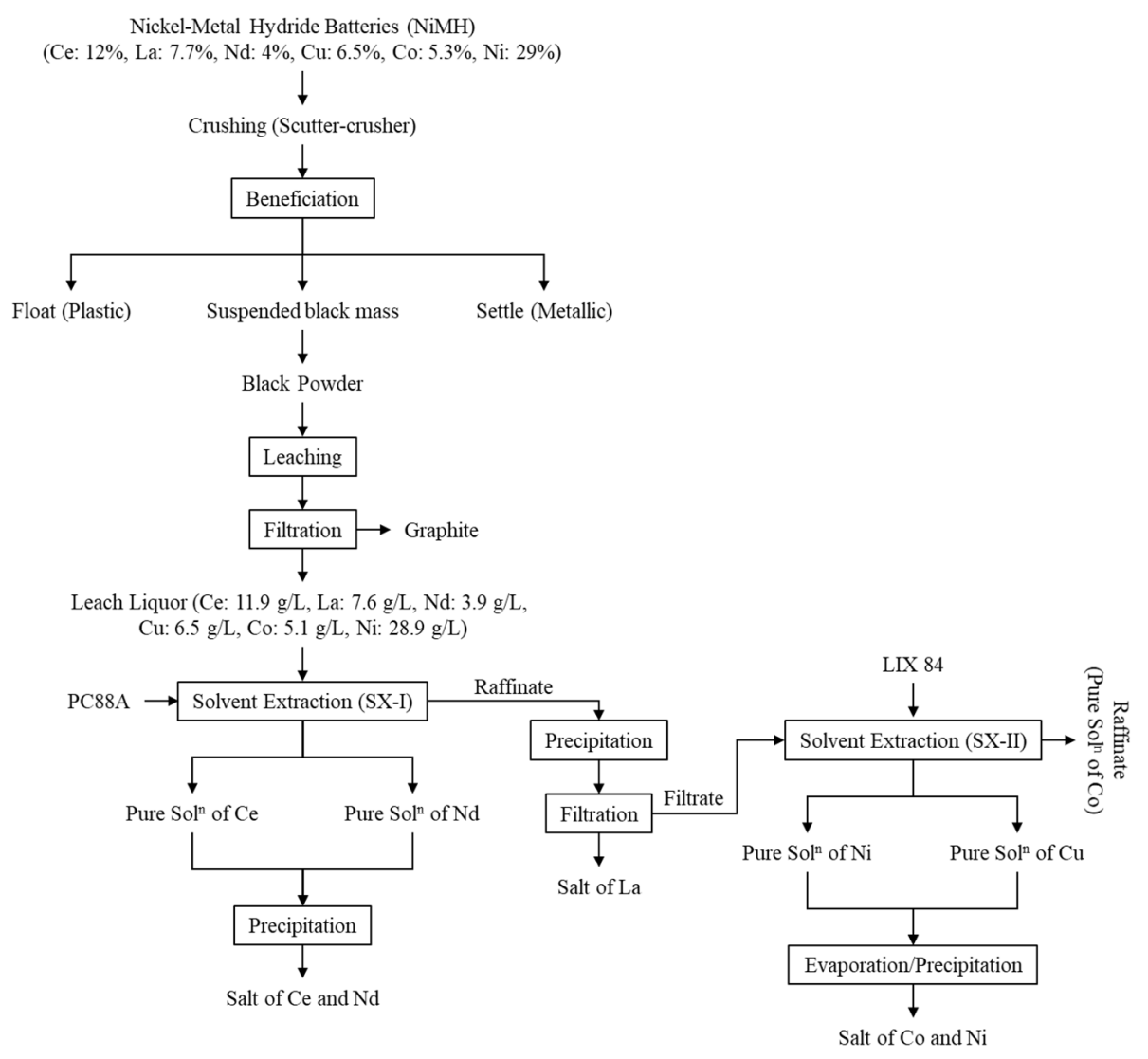

Figure 12. Developed process flowsheet for extraction of rare metals, $\mathrm{Cu}, \mathrm{Ni}$ and $\mathrm{Co}$ from discarded $\mathrm{NiMH}$ batteries of electric vehicles. 


\section{Conclusions}

Based on laboratory scale studies, the following conclusions have been drawn for the recovery of rare and valuable metals from $\mathrm{NiMH}$ batteries of electric vehicles:

(1) It was found that more than $98.9 \% \mathrm{La}, 98.5 \% \mathrm{Nd}, 89.9 \% \mathrm{Ce}, 99 \% \mathrm{Cu}, 99 \% \mathrm{Ni}$ and $95.9 \%$ Co were leached in $2 \mathrm{M} \mathrm{H}_{2} \mathrm{SO}_{4}$ at $75{ }^{\circ} \mathrm{C}$ in $60 \mathrm{~min}$ in the presence of $10 \% \mathrm{H}_{2} \mathrm{O}_{2}(\mathrm{v} / \mathrm{v})$.

(2) Further, $\mathrm{Nd}$ and Ce were extracted using 10\% PC 88A at equilibrium pH 1.5. A McCabe-Thiele plot showed that $99 \% \mathrm{Nd}$ was extracted with PC 88A at eq. $\mathrm{pH} \sim 1.5$ at $\mathrm{O} / \mathrm{A}$ ratio $1 / 1$ in two counter-current stages.

(3) After the extraction of $\mathrm{Nd}$ and $\mathrm{Ce}, 99 \%$ La was selectively precipitated with sodium hydroxide at room temperature between $\mathrm{pH} 1.5$ and 2.0, leaving $\mathrm{Cu}, \mathrm{Ni}$ and $\mathrm{Co}$ in the raffinate.

(4) Subsequently, $\mathrm{Cu}$ and Ni were selectively extracted using LIX 84 at eq. $\mathrm{pH} \sim 2.5$ and $\sim 5$, respectively, leaving $\mathrm{Co}$ in the raffinate.

Author Contributions: Methodology, P.K.C. and O.S.D.; writing-original draft preparation, R.P. and P.K.C.; writing-review and editing, M.K.J., K.Y. and I.P.; supervision, M.K.J. and R.K.J.; project administration, M.K.J. and I.P.; funding acquisition, I.P. All authors have read and agreed to the published version of the manuscript.

Funding: This study was partially supported by the Japan Society for the Promotion of Science (JSPS) Grant-in-Aid for Early-Career Scientists (JP20K15214). The work has been supported by CSIRNML under Urban Ore Recycling Centre (FTC-0014/MLP-3116) and various Indo-Korean long term collaboration programs.

Data Availability Statement: The data presented in this study are available on request from the corresponding author.

Acknowledgments: The authors are grateful to the Director CSIR-National Metallurgical Laboratory, Jamshedpur, India for giving permission to publish the paper and work done under CSIR-NML projects and international collaborations.

Conflicts of Interest: The authors declare no conflict of interest.

\section{References}

1. Ahn, N.K.; Swain, B.; Shim, H.W.; Kim, D.W. Recovery of rare earth oxide from waste NiMH batteries by simple wet chemical valorization process. Metals 2019, 9, 1151. [CrossRef]

2. Kumari, A.; Parween, R.; Chakravarty, S.; Parmar, K.; Patha, D.D.; Lee, J.C.; Jha, M.K. Novel approach to recover rare earth metals (REMs) from Indian coal bottom ash. Hydrometallurgy 2019, 187, 1-7. [CrossRef]

3. Park, I.; Kanazawa, Y.; Sato, N.; Galtchandmani, P.; Jha, M.K.; Tabelin, C.B.; Jeon, S.; Ito, M.; Hiroyoshi, N. Beneficiation of Low-Grade Rare Earth Ore from Khalzan Buregtei Deposit (Mongolia) by Magnetic Separation. Minerals 2021, 11, 1432. [CrossRef]

4. Cui, J.; Forssberg, E. Mechanical recycling of waste electric and electronic equipment: A review. J. Hazard Mater. 2003, 99, 243-263. [CrossRef]

5. Choubey, P.K.; Singh, N.; Panda, R.; Jyothi, R.K.; Yoo, K.; Park, I.; Jha, M.K. Development of Hydrometallurgical Process for Recovery of Rare Earth Metals (Nd, Pr, and Dy) from Nd-Fe-B Magnets. Minerals 1987, 11, 1987. [CrossRef]

6. Tan, Q.Y.; Li, J.H.; Zeng, X.L. Rare Earth Elements Recovery from Waste Fluorescent Lamps: A Review. Crit. Rev. Environ. Sci. Technol. 2015, 45, 749-776. [CrossRef]

7. Ying, T.K.; Gao, X.P.; Hu, W.K.; Wu, F.; Noreus, D. Studies on rechargeable NiMH batteries. Int. J. Hydrogen Energy 2005, 31, 525-530. [CrossRef]

8. Jung, D.Y.; Lee, B.H.; Kim, S.W. Development of battery management system for nickel-metal hydride batteries in electric vehicle applications. J. Power Sources 2002, 109, 1-10. [CrossRef]

9. Zhi, H.; Ni, S.; Su, X.; Xie, W.; Zhang, H.; Sun, X. Separation and recovery of rare earth from waste nickel-metal hydride batteries by phosphate based extraction-precipitation. J. Rare Earths 2021. in Press. [CrossRef]

10. Tanabe, E.H.; Schlemmer, D.F.; Aguiar, M.L.; Dotto, G.L.; Bertuol, D.A. Recovery of valuable materials from spent NiMH batteries using spouted bed elutriation. J. Environ. Manag. 2016, 171, 177-183. [CrossRef]

11. Samane, M.; Khayyam, N.R.; Rumana, H.; Mohammad, A.; Veena, S. Recovery of rare earth (i.e., La, Ce, Nd, and Pr) oxides from end-of-life Ni-MH battery via thermal isolation. ACS Sustain. Chem. Eng. 2018, 6, 11811-11818.

12. Innocenzi, V.; Ippolito, N.M.; Michelis, I.D.; Prisciandaro, M.; Medici, F.; Veglio, F. A review of the processes and lab-scale techniques for the treatment of spent rechargeable NiMH batteries. J. Power Sources 2017, 362, 202-218. [CrossRef] 
13. Jha, M.K.; Kumari, A.; Panda, R.; Kumar, J.R.; Yoo, K.; Lee, J.Y. Review on hydrometallurgical recovery of rare earth metals. Hydrometallurgy 2016, 165, 2-26. [CrossRef]

14. Li, L.Y.; Xu, S.M.; Ju, Z.Y.; Wu, F. Recovery of Ni, Co and rare earths from spent Ni-metal hydride batteries and preparation of spherical $\mathrm{Ni}(\mathrm{OH})_{2}$. Hydrometallurgy 2009, 100, 41-46. [CrossRef]

15. Al-Thyabat, S.; Nakamura, T.; Shibata, E.; lizuka, A. Adaptation of minerals processing operations for lithium-ion (LiBs) and nickel metal hydride (NiMH) batteries recycling: Critical review. Miner Eng. 2013, 45, 4-17. [CrossRef]

16. Bernardes, A.M.; Espinosa, D.C.R.; Tenorio, J.A.S. Recycling of batteries: A review of current processes and technologies. J. Power Sources 2004, 130, 291-298. [CrossRef]

17. Korkmaz, K.; Alemrajabi, M.; Rasmuson, A.; Forsberg, K. Recoveries of valuable metals from spent nickel metal hydride vehicle batteries via sulfation, selective roasting, and water leaching. J. Sustain. 2018, 4, 313-325. [CrossRef]

18. Bertuol, D.A.; Bernardes, A.M.; Tenorio, J.A.S. Spent NiMH batteries-the role of selective precipitation in the recovery of valuable metals. J. Power Sources 2009, 193, 914-923. [CrossRef]

19. Innocenzi, V.; Veglio, F. Recovery of rare earths and base metals from spent nickel-metal hydride batteries by sequential sulphuric acid leaching and selective precipitations. J. Power Sources 2012, 211, 184-191. [CrossRef]

20. Yang, X.; Zhang, J.; Fang, X. Rare earth element recycling from waste nickel-metal hydride batteries. J. Hazard Mater. 2014, 279, 384-388. [CrossRef]

21. Fernandes, A.; Afonso, J.C.; Dutra, A.J.B. Separation of nickel(II), cobalt(II) and lanthanides from spent Ni-MH batteries by hydrochloric acid leaching, solvent extraction and precipitation. Hydrometallurgy 2013, 133, 37-43. [CrossRef]

22. Zhang, P.; Yokoyama, T.; Itabashi, O.; Wakui, Y.; Suzuki, T.M.; Inoue, K. Hydrometallurgical process for recovery of metal values from spent nickel-metal hydride secondary batteries. Hydrometallurgy 1998, 50, 61-75. [CrossRef]

23. Xia, Y.; Xiao, L.; Tian, J.; Li, Z.; Zeng, L. Recovery of rare earths from acid leach solutions of spent nickel-metal hydride batteries using solvent extraction. J. Rare Earths 2015, 33, 1348-1354. [CrossRef]

24. Zhang, P.W.; Yokoyama, T.; Itabashi, O.; Wakui, Y.; Suzuki, T.M.; Inoue, K. Recovery of metal values from spent nickel-metal hydride rechargeable batteries. J. Power Sources 1999, 77, 116-122. [CrossRef]

25. Larsson, K.; Ekberg, C.; Jensen, A.Q. Using Cyanex 923 for selective extraction in a high concentration chloride medium on nickel metal hydride battery waste. Hydrometallurgy 2012, 129-130, 35-42. [CrossRef]

26. Zhang, W.C.; Noble, A.; Ji, B.; Li, Q. Effects of contaminant metal ions on precipitation recovery of rare earth elements using oxalic acid. J. Rare Earths 2020, in press. [CrossRef]

27. Mei, G.J.; Xia, Y.; Shi, W.; Liu, B. Recovery of rare earth from spent MH-Ni battery negative electrode. Environ. Prot. Chem. Ind. 2008, 28, 70-73.

28. Pietrelli, L.; Bellomo, B.; Fontana, D.; Montereali, M. Characterization and leaching of NiCd and NiMH spent batteries for the recovery of metals. Waste Manag. 2005, 25, 221-226. [CrossRef] [PubMed]

29. Ahn, N.K.; Shim, H.-W.; Kim, D.-W.; Swain, B. Valorization of waste NiMH battery through recovery of critical rare earth metal: A simple recycling process for the circular economy. Waste Manag. 2020, 104, 254-261. [CrossRef]

30. Kumari, A.; Jha, M.K.; Pathak, D.D. An innovative environmental process for the treatment of scrap Nd-Fe-B magnets. J. Environ. Manag. 2020, 273, 111063. [CrossRef]

31. Kumari, A.; Jha, M.K.; Yoo, K.; Panda, R.; Lee, J.Y.; Kumar, R.J.; Pathak, D.D. Advanced process to dephosphorize monazite for effective leaching of rare earth metals (REMs). Hydrometallurgy 2019, 187, 203-211. [CrossRef] 